\title{
Aminorex (Menocil) and amphetamine: acute and chronic effects on pulmonary and systemic haemodynamics in the calf
}

\author{
EDWARD BYRNE-QUINN and ROBERT F. GROVER \\ Cardiovascular Pulmonary Research Laboratory, Department of Medicine, \\ University of Colorado Medical Center, Denver, Colorado 80220, U.S.A.
}

\begin{abstract}
Reports of pulmonary hypertension in obese women treated with the appetite suppressant aminorex (Menocil) prompted this study using the calf as a model because of its very reactive pulmonary vascular bed. Acute and chronic haemodynamic effects were observed following daily intravenous injections of aminorex $(0.25 \mathrm{mg} / \mathrm{kg}$ as free base) in four calves. Four other calves were similarly treated with the related sympathomimetic drug amphetamine in the same dose, and four calves served as controls. The acute effects of both these drugs were a significant increase in systemic arterial pressure and resistance with no change in pulmonary haemodynamics. The chronic effect of one month's treatment was to leave both systemic and pulmonary haemodynamics unchanged, and there was no depletion in endogenous catecholamines as measured by the tyramine test. In addition, the reactivity of the pulmonary vascular bed to hypoxia remained unaltered. Thus neither aminorex nor amphetamine produced pulmonary hypertension during one month's treatment in the calf.
\end{abstract}

Aminorex (Menocil) is 2-amino-5-phenyl oxazoline and, like amphetamine, has a chemical structure similar to that of adrenaline (Fig. 1). Both aminorex and amphetamine produce their pharmacological effects by releasing endogenous catecholamines, and both drugs suppress appetite (Poos et al., 1963; Chardonnens and Mahaim, 1969). Because aminorex is an anorexigen, it came into widespread clinical use in 1965 for the treatment of obesity in Switzerland, western Germany, and Austria. Within a year, medical centres in those three countries began to report a striking increase in the incidence of primary pulmonary hypertension, and many of the patients were obese women who had taken aminorex (Gurtner et al.,
1968 ; Kaindl, 1969 ; Rivier, 1970). This circumstantial evidence gave rise to the suspicion that aminorex might have played an aetiological role in some of those cases of pulmonary hypertension.

Except for substances which mechanically obstruct pulmonary blood vessels, e.g., emboli, few agents can produce sustained pulmonary hypertension. Of these, alveolar hypoxia is well known as a potent pulmonary vasoconstrictor. Chronic ingestion of the seeds of Crotolaria spectabilis, which contain monocrotaline, will produce severe pulmonary hypertension in animals and man (Kay and Heath, 1969). However, no sympathomimetic drug has ever been shown to be capable of producing chronic pulmonary hypertension. There-

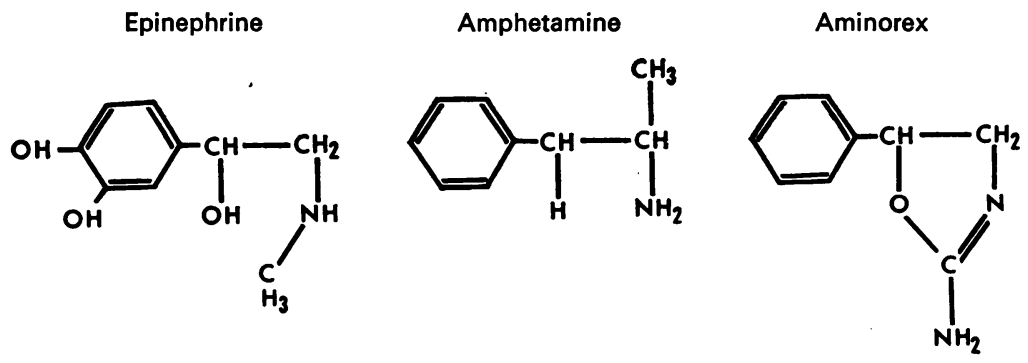

FIG. 1. Similar chemical structures of epinephrine (adrenaline), amphetamine, and aminorex. 
fore, it would be remarkable, although of great interest, if significant pulmonary hypertension did result from the continual release of endogenous catecholamines by either aminorex or amphetamine. The present investigation was undertaken to explore this possibility.

\section{METHODS}

Twelve Hereford heifers, 3 to 4 months old, were obtained from a herd native to $1,500 \mathrm{~m}$ altitude. They were studied in Denver at $1,600 \mathrm{~m}$ where the barometric pressure of 625 torr creates mild atmospheric hypoxia and hence mild alveolar hypoxia (PAO2 circa 80 torr).

In all animals the external jugular vein was punctured percutaneously with a $14 \mathrm{~T}$ needle. A polyethylene catheter (PE 160) was passed through this and floated into the pulmonary artery, as determined by monitoring intravascular pressure. The $14 \mathrm{~T}$ needle was then removed and the catheter was left in situ for the duration of the study (one month). This facilitated measurements of pulmonary artery pressure and the daily intravenous injection of the test drugs.

The 12 calves were divided at random into three groups of four. One group served as controls, and $6 \mathrm{ml}$ of $0.9 \%$ sodium chloride were injected once daily for 28 days into the pulmonary artery catheter. The second group received $6 \mathrm{ml}$ of an aqueous solution of aminorex fumarate containing $0.25 \mathrm{mg} / \mathrm{kg}$ calculated as the free base. The third group was given $6 \mathrm{ml}$ of an aqueous solution of amphetamine sulphate containing $0.25 \mathrm{mg} / \mathrm{kg}$, also calculated as the free base.
Complete haemodynamic measurements were performed on each animal at the time treatment began, and after two and four weeks' treatment. In addition, 흠 after one and three weeks' treatment, pulmonary $\frac{0}{2}$ artery pressure only was measured. The animals were $\mathbb{\Omega}$ studied standing in a cattle stanchion and pulmonary artery pressure was measured via the indwelling ${ }^{\mathcal{S}}$ catheter with a strain gauge pressure transducer $\vec{O}$ (Statham model P23Db). Aortic pressure was measured using a similar transducer by direct needle puncture $\vec{\omega}$ of the thoracic aorta through the 11 th or 12 th rib? interspace (Stowe and Good, 1960). The zero refer-安 ence point was taken as being halfway between thei sternum and the spine. Mean pressures were obtained. by electrical damping. Heart rate was measured from ${ }_{-}$ the electrocardiogram. Arterial blood $\mathrm{PO}_{2}, \mathrm{PcO}_{2}$, and $\underset{N}{ }$ pH were measured with the appropriate electrodeso (Radiometer, Copenhagen) and corrected for body temperature (rectal). Cardiac output was measured by ${ }_{\vec{C}}^{-}$ the indicator dilution technique using Cardiogreen@ and a densitometer (Waters Corp., Rochester, Minn., model X250). Injection was made into the pulmonary artery and sampling was made from the aorta. All recordings were made on a polygraph (Gilson, M5P). Total pulmonary resistance to blood flow was cal-N culated by dividing the mean pulmonary artery pressure by cardiac output.

At the time of each haemodynamic study, 24 hours had elapsed since the last injection of the test drug. Initial measurements were made while the animalo breathed ambient air $\left(\mathrm{Plo}_{2} 120 \mathrm{mmHg}\right)$. Next, with å tight-fitting face mask and a Rudolph valve (Warren $\overrightarrow{\vec{A}}$ E. Collins), the animal was rendered hypoxic by the $\frac{0}{3}$ administration of a gas mixture containing $7.5 \% \mathrm{O}_{2}$

T A B LE I

PULMONARY HAEMODYNAMICS

\begin{tabular}{|c|c|c|c|c|c|c|c|c|}
\hline & \multirow{2}{*}{$\mathrm{PaO}_{2}$} & \multirow{2}{*}{$\begin{array}{l}\text { Group } \\
(n=4)\end{array}$} & & \multicolumn{5}{|c|}{ Day } \\
\hline & & & & 0 & 7 & 14 & 21 & 28 \\
\hline & $\begin{array}{l}63 \cdot 1 \\
(4 \cdot 4)\end{array}$ & Control & $\begin{array}{l}\text { PPA } \\
\text { TPR }\end{array}$ & $\begin{array}{r}26.5 \pm 1 \cdot 3 \\
134 \cdot 3 \pm 17 \cdot 3\end{array}$ & $\begin{array}{c}27.5 \pm 1.0 \\
-\end{array}$ & $\begin{array}{l}25.5 \pm 1.7 \\
89.0 \pm 6.7\end{array}$ & $28.8 \pm 3.5$ & $\begin{array}{r}28.8 \pm 1.0 \\
113.3 \pm 10.4\end{array}$ \\
\hline \multirow[t]{3}{*}{ Normoxia } & $\begin{array}{l}66 \cdot 5 \\
(3 \cdot 7)\end{array}$ & Aminorex & $\begin{array}{l}\text { PPA } \\
\text { TPR }\end{array}$ & $\begin{array}{l}26 \cdot 3 \pm 1.0 \\
94 \cdot 0 \pm 11.6\end{array}$ & $\begin{array}{c}31.0 \pm 3.0 \\
--\end{array}$ & $\begin{array}{r}30 \cdot 8 \pm 2 \cdot 3 \\
109 \cdot 0 \pm 14 \cdot 8\end{array}$ & $\begin{array}{c}32 \cdot 8 \pm 2 \cdot 9 \\
--\end{array}$ & $\begin{array}{r}31 \cdot 7 \pm 1.9 \\
126 \cdot 0 \pm 23 \cdot 3\end{array}$ \\
\hline & $\begin{array}{l}66 \cdot 5 \\
(6 \cdot 7)\end{array}$ & Amphetamine & $\begin{array}{l}\text { PPA } \\
\text { TPR }\end{array}$ & $\begin{array}{r}32 \cdot 0 \pm 4 \cdot 1 \\
121 \cdot 8 \pm 12 \cdot 9\end{array}$ & $\begin{array}{c}33.5 \pm 1.9 \\
--\end{array}$ & $\begin{array}{r}32 \cdot 8 \div 2 \cdot 3 \\
113 \cdot 3 \pm 2 \cdot 8\end{array}$ & $\begin{array}{c}36 \cdot 3 \pm 3 \cdot 3 \\
-\end{array}$ & $\begin{array}{r}38 \cdot 3 \pm \quad 0 \cdot 9 \\
138 \cdot 3 \pm \quad 5 \cdot 8\end{array}$ \\
\hline & $\begin{array}{l}30 \cdot 4 \\
(3 \cdot 4)\end{array}$ & Control & $\begin{array}{l}\text { PPA } \\
\text { TPR }\end{array}$ & $\begin{array}{r}65 \cdot 3 \pm 7 \cdot 5 \\
221 \cdot 7 \pm 40 \cdot 0\end{array}$ & $\begin{array}{c}68.0 \pm 3.4 \\
-\quad-\end{array}$ & $\begin{array}{r}59.5 \pm 5.4 \\
152.7 \pm 13.2\end{array}$ & $\begin{array}{c}63 \cdot 0 \pm 6 \cdot 1 \\
--\end{array}$ & $\begin{array}{r}69 \cdot 8 \pm \quad 6 \cdot 5 \\
204 \cdot 0 \pm 40 \cdot 0\end{array}$ \\
\hline \multirow[t]{3}{*}{$\begin{array}{l}\text { Acute } \\
\text { hypoxia }\end{array}$} & $\begin{array}{l}29 \cdot 3 \\
(1 \cdot 7)\end{array}$ & Aminorex & $\begin{array}{l}\text { PPA } \\
\text { TPR }\end{array}$ & $\begin{array}{r}72 \cdot 5 \\
165 \cdot 0 \\
18 \cdot 0\end{array}$ & $\begin{array}{c}79.0 \pm 7.6 \\
--\end{array}$ & $\begin{array}{r}77 \cdot 5 \pm 5 \cdot 3 \\
185 \cdot 8 \pm 22 \cdot 9\end{array}$ & $\begin{array}{c}82 \cdot 3 \leq 7 \cdot 4 \\
--\end{array}$ & $\begin{array}{r}77 \cdot 8 \pm \quad 5 \cdot 7 \\
288 \cdot 3 \pm 110 \cdot 5\end{array}$ \\
\hline & $\begin{array}{c}28.6 \\
(3 \cdot 0) \\
\end{array}$ & Amphetamine & $\begin{array}{l}\text { PPA } \\
\text { TPR }\end{array}$ & $\begin{array}{r}80 \cdot 8 \pm 9 \cdot 6 \\
242 \cdot 3 \pm 40 \cdot 5\end{array}$ & $\begin{array}{c}75 \cdot 0 \pm 7 \cdot 8 \\
-\square\end{array}$ & $\begin{array}{r}62 \cdot 8 \pm 9 \cdot 4 \\
172 \cdot 5 \pm 39 \cdot 8\end{array}$ & $\begin{array}{c}83.8 \pm 11.9 \\
-\square\end{array}$ & $\begin{array}{c}85 \cdot 3 \pm 7 \cdot 2 \\
305 \cdot 3 \pm 82 \cdot 2\end{array}$ \\
\hline & $\begin{array}{l}65 \cdot 3 \\
(3 \cdot 7)\end{array}$ & Control & $\begin{array}{l}\text { PPA } \\
\text { TPR }\end{array}$ & 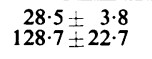 & $\begin{array}{c}31.3 \pm 0.5 \\
-\end{array}$ & $\begin{array}{r}28 \cdot 3 \pm 3 \cdot 9 \\
110 \cdot 3 \pm 13 \cdot 5\end{array}$ & $29 \cdot 3 \div 3 \cdot 3$ & $2^{33 \cdot 8^{1} \pm}{ }^{6 \cdot 0}$ \\
\hline \multirow[t]{2}{*}{ Acute drug } & $\begin{array}{l}66 \cdot 7 \\
(6 \cdot 6)\end{array}$ & Aminorex & $\begin{array}{l}\text { PPA } \\
\text { TPR }\end{array}$ & $\begin{array}{l}29 \cdot 8 \pm 4 \cdot 8 \\
97 \cdot 3 \pm 20 \cdot 6\end{array}$ & $\begin{array}{c}32 \cdot 0 \div 3 \cdot 2 \\
-\quad-\end{array}$ & $\begin{array}{r}30 \cdot 3 \div 2 \cdot 0 \\
107.0=8.4\end{array}$ & $35 \cdot 5 \div 4 \cdot 2$ & $34 \cdot 7^{1} \pm 3.7$ \\
\hline & $\begin{array}{l}67 \cdot 1 \\
(5 \cdot 0)\end{array}$ & Amphetamine & $\begin{array}{l}\text { PPA } \\
\text { TPR }\end{array}$ & $\begin{array}{r}40 \cdot 3 \pm 4.9 \\
158 \cdot 8 \pm 19.9\end{array}$ & $35 \cdot 5 \pm 1 \cdot 9$ & $\begin{array}{r}35 \cdot 8 \div 2 \cdot 5 \\
127 \cdot 8 \pm 6 \cdot 1\end{array}$ & ${ }^{35.0}: 3.5$ & $\underline{-37}^{2 \cdot 3}$ \\
\hline \multicolumn{9}{|c|}{$\begin{array}{l}\mathrm{PaO}_{2}=\text { mean arterial oxygen tension, torr (S.D.). } \\
\mathrm{PPA}=\text { mean pulmonary artery pressure } \pm \text { S.E.M. } \\
\mathrm{TPR}=\text { total pulmonary vascular resistance, dynes } \mathrm{sec} \mathrm{cm}^{-5} \pm \text { S.E.M. } \\
{ }^{\mathrm{T}} \mathrm{Ty} \text { ramine } 0.1 \mathrm{mg} / \mathrm{kg} \text { instead of drug. }\end{array}$} \\
\hline
\end{tabular}


$\left(\mathrm{PIO}_{2}=47\right.$ torr $)$ and $4 \% \mathrm{CO}_{2}\left(\mathrm{PICO}_{2}=25\right.$ torr $)$, balance $\mathrm{N}_{2}$, and all measurements were repeated when pulmonary artery pressure had stabilized, usually within 3 to 5 minutes. After 15 minutes' recovery, the usual daily dose of drug was given intravenously, pulmonary artery and aortic pressures were monitored continuously, and measurements of blood gases and cardiac output were again made after 3 minutes. On the final, 28 th day, instead of being given the allocated drug, each surviving animal underwent a tyramine test to show whether or not catecholamine depletion had occurred (Gaffney, Morrow, and Chidsey, 1962). An intravenous injection of $0.1 \mathrm{mg} / \mathrm{kg}$ tyramine hydrochloride was given while the pulmonary artery pressure, aortic pressure, and heart rate were monitored.

All variables measured were subjected to a threefactor analysis of variance (Scheffé, 1959).

\section{RESULTS}

PUlmonary haEmodynamics (Table I) Before treatment, mean pulmonary arterial pressure (PPA) in all three groups of animals was within the range of normal for calves living at an altitude of 1,600 m (Reeves, Grover, Will, and Alexander, 1962). By chance, the group selected to receive amphetamine had an initial PPA of $32 \cdot 0 \pm 4 \cdot 1$ $\mathrm{mmHg}$ compared with $26.5 \pm 1.3 \mathrm{mmHg}$ in the control group and $26.3 \pm 1.0 \mathrm{mmHg}$ in the group destined to receive aminorex. Daily treatment for one month produced a slight but non-significant increase in PPA in all three groups (Fig. 2). It is

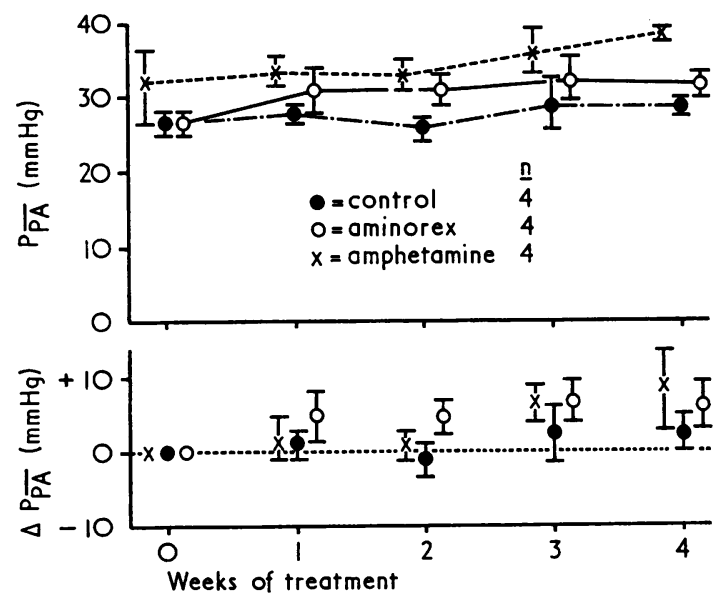

FIG. 2. Mean pulmonary artery pressures \pm 1 S.E.M.

noteworthy that after daily injections of aminorex for one month, PPA was $31.7 \pm 1.9 \mathrm{mmHg}$, which is no higher than the initial pressures of $32 \cdot 0 \pm 4 \cdot 1$
$\mathrm{mmHg}$ in the amphetamine group before any drug treatment. Thus, pulmonary hypertension did not result from the chronic administration of aminorex or amphetamine (or saline). Neither was there a significant increase in total pulmonary resistance (TPR) in any of the three groups.

Acute hypoxia lowered $\mathrm{PaO}_{2}$ from 65 torr to 30 torr and produced hyperventilation. However, the presence of $4 \% \mathrm{CO}_{2}$ in the inspired hypoxic gas mixture prevented hypocapnia and thus avoided the development of alkalosis which might have attenuated the pulmonary pressor response (Ferrer, Enson, and Harvey, 1969). Consequently, acute hypoxia produced a rise in PrA (Fig. 3) of the

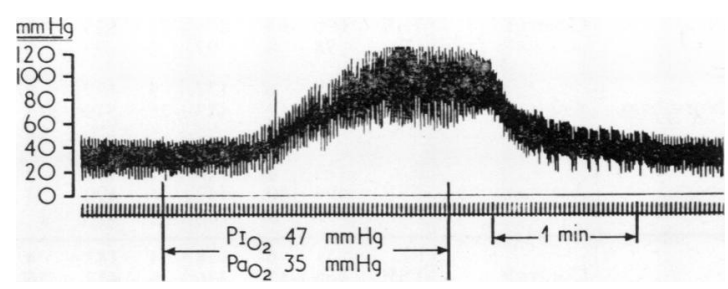

FIG. 3. Typical pulmonary hypertensive response to hypoxia in the calf.

order of $40 \mathrm{mmHg}$. This resulted from an increase in both TPR and cardiac output. One month's treatment with sympathomimetic drugs did not enhance the pulmonary vascular responsiveness to acute hypoxia.

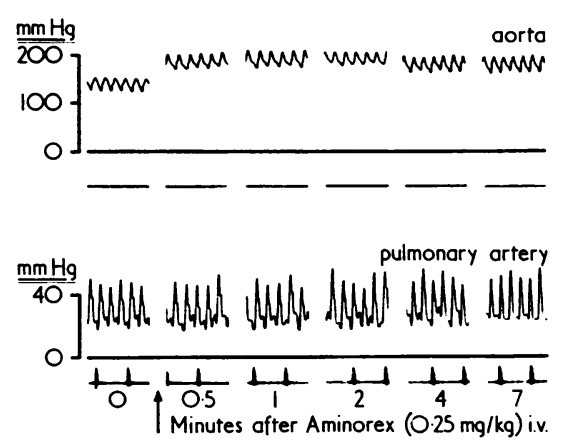

FIG. 4. Typical acute response to aminorex. There is a significant rise in aortic pressure but no change in pulmonary artery pressure. A similar response occurred with amphetamine.

The acute response to the injection of $6 \mathrm{ml}$ of saline into the pulmonary artery was a variable and non-significant rise in PPA of 2-4 $\mathrm{mmHg}$. 
Neither aminorex nor amphetamine produced a rise in PPA any greater than this. Thus, while these drugs did produce a transient systemic pressure rise, they had no acute pulmonary pressor effect (Fig. 4).

SYSTEMIC HAEMODYNAMICS (Table II) Systemic arterial pressure, total systemic resistance (TSR),

T A B LE II

SYSTEMIC HAEMODYNAMICS AND HEART RATE MEAN VALUES \pm S.E.M.

\begin{tabular}{|c|c|c|c|c|c|}
\hline & \multirow{2}{*}{$\begin{array}{l}\text { Group } \\
(\mathrm{n}=4)\end{array}$} & \multicolumn{4}{|c|}{ Day } \\
\hline & & & 0 & 14 & 28 \\
\hline \multirow{3}{*}{ Normoxia } & Control & $\mid \begin{array}{l}\mathbf{P}_{A 0} \\
\mathbf{T S R}_{\mathbf{T R}} \\
\mathbf{H R}\end{array}$ & $\begin{array}{r}147 \pm 3 \\
690 \pm 65 \\
98 \pm 8\end{array}$ & $\begin{array}{r}132 \pm 5 \\
471 \pm 35 \\
97 \pm 2\end{array}$ & $\begin{array}{rr}135 \pm & 2 \\
525 \pm & 39 \\
99 \pm & 9\end{array}$ \\
\hline & Aminorex & $\begin{array}{l}\mathbf{P}_{\text {Ao }} \\
\text { TSR } \\
\text { HR }\end{array}$ & $\begin{array}{r}129 \pm 6 \\
463 \pm 19 \\
99 \pm 5\end{array}$ & $\begin{array}{r}137 \pm 9 \\
473 \pm 25 \\
95 \pm 4\end{array}$ & $\begin{array}{l}137 \pm 9 \\
549 \pm 113 \\
120 \pm 28\end{array}$ \\
\hline & Amphetamine & $\begin{array}{l}\mathbf{P}_{\text {AO }} \\
\text { TSR } \\
\text { HR }\end{array}$ & $\begin{array}{l}125 \pm 4 \\
494 \pm 40 \\
100 \pm 5\end{array}$ & $\begin{array}{l}118 \pm 10 \\
447 \pm 46 \\
106 \pm 5\end{array}$ & $\begin{array}{l}134 \pm \quad 7 \\
490 \pm 54 \\
91 \pm 1\end{array}$ \\
\hline \multirow{3}{*}{$\begin{array}{l}\text { Acute } \\
\text { hypoxia }\end{array}$} & Control & $\begin{array}{l}\mathbf{P}_{\text {AO }} \\
\text { TSR } \\
\text { HR }\end{array}$ & $\begin{array}{l}151 \pm 6 \\
466 \pm 15 \\
164 \pm 20\end{array}$ & $\begin{array}{l}138 \pm 4 \\
336 \pm 26 \\
170 \pm 5\end{array}$ & $\begin{array}{l}143 \pm \quad 4 \\
412 \pm 56 \\
183 \pm 10\end{array}$ \\
\hline & Aminorex & $\begin{array}{l}\mathbf{P}_{\text {AO }} \\
\text { TSR } \\
\text { HR }\end{array}$ & $\begin{array}{l}154 \pm 6 \\
361 \pm 50 \\
158 \pm 16\end{array}$ & $\begin{array}{l}135 \pm 6 \\
318 \pm 11 \\
168 \pm 6\end{array}$ & $\begin{array}{l}146 \pm 1 \\
519 \pm 161 \\
183 \pm 3\end{array}$ \\
\hline & Amphetamine & \begin{tabular}{|l}
$\mathbf{P}_{\mathbf{A l}}$ \\
TSR \\
HR
\end{tabular} & $\begin{array}{l}134 \pm 6 \\
395 \pm 38 \\
168 \pm 4\end{array}$ & $\begin{array}{l}132 \pm 9 \\
350 \pm 25 \\
166 \pm 5\end{array}$ & $\begin{array}{l}118 \pm \\
396 \pm \\
174 \pm 27\end{array}$ \\
\hline \multirow{3}{*}{ Acute drug } & Control & $\begin{array}{l}\mathbf{P}_{\text {AO }} \\
\text { TSR } \\
\text { HR }\end{array}$ & $\begin{array}{l}140 \pm 5 \\
598 \pm 67 \\
101 \pm 9\end{array}$ & $\begin{array}{r}124 \pm 2 \\
485 \pm 18 \\
89 \pm 3\end{array}$ & $\begin{array}{r}160^{1} \pm 5 \\
\overline{93} \pm-9\end{array}$ \\
\hline & Aminorex & $\begin{array}{l}\text { PAO }_{\text {AO }} \\
\text { TSR } \\
\text { HR }\end{array}$ & $\begin{array}{r}160 \pm 8 \\
579 \pm 36 \\
91 \pm 4\end{array}$ & $\begin{array}{r}168 \pm 6 \\
602 \pm 39 \\
97 \pm 4\end{array}$ & $\frac{160^{1} \pm 12}{107 \pm 19}$ \\
\hline & Amphetamine & $\begin{array}{l}\text { PAO }_{\text {AO }} \\
\text { TSSR } \\
\text { HR }\end{array}$ & $\begin{array}{r}174 \pm 8 \\
713 \pm 63 \\
88 \pm 9\end{array}$ & $\begin{array}{l}171 \pm 7 \\
623 \pm 59 \\
111 \pm 8\end{array}$ & $\frac{182^{1} \pm 8}{72 \pm-2}$ \\
\hline
\end{tabular}

$\mathbf{P}_{A 0}=$ mean aortic pressure (mmHg).

$\mathrm{TSR}=$ total systemic resistance (dynes sec $\mathrm{cm}^{-5}$ ).

HR = heart rate per minute.

1 Tyramine $0.1 \mathrm{mg} / \mathrm{kg}$ instead of drug.

and heart rate showed no significant or progressive change during the one month of treatment. This was in spite of the fact that aminorex produced an acute but transient rise in mean aortic pressure of $30 \mathrm{mmHg}$ and a $25 \%$ increase in TSR, while the change in heart rate was variable and not significant. Similarly, the acute response to amphetamine was an increase in mean aortic pressure of $50 \mathrm{mmHg}$ and a $40-45 \%$ increase in TSR; again, there was no consistent reflex slowing of the heart rate. The highly significant acute systemic pressor responses to aminorex and amphetamine indicate that the dosage employed, $0.25 \mathrm{mg} / \mathrm{kg}$, was pharmacologically 'effective'.
Thus, the daily administration of sympathomimetic drugs did not produce sustained systemic hypertension. In addition, after 28 days of treatment the responses to tyramine indicated that the endogenous stores of catecholamines had not been depleted. In each of the three groups, tyramine produced a significant rise in aortic pressure and a reflex decrease in heart rate.

During acute hypoxia, there was a marked tachycardia, an increase in cardiac output, and a decrease in TSR. This pattern of response did not change during the one month of study.

Body weight did not change significantly in any of the three groups of calves during the course of this investigation. Thus, the effects on weight of the daily administration of appetite suppressants were similar to the effects of a daily injection of saline.

COMPLICATIONS On the $23 \mathrm{rd}$ day, one animal in the amphetamine group died, and on the 25 th day one animal in the aminorex group also died. In both animals, death was preceded by tachycardia, fever, and dyspnoea. We suspected that there was sepsis and pulmonary infarction due to the indwelling pulmonary artery catheters, and this was confirmed at necropsy which also showed that the catheters were extensively coated with fibrin. One of the control animals developed similar symptoms the day after the study concluded and was therefore sacrificed; the necropsy changes resembled those found in the other two. These complications did not cause pulmonary hypertension in any of the three calves.

\section{DISCUSSION}

The calf (bas taurus) was considered to be the ideal experimental animal for this investigation. This species has a remarkably reactive pulmonary vascular bed and will develop severe pulmonary hypertension when exposed to the stimulus of chronic atmospheric hypoxia ( $\mathrm{PIO}_{2} 90$ torr). The milder degree of atmospheric hypoxia $\left(\mathrm{PIO}_{2} 120\right.$ o torr) which exists in Denver (PB 625 torr) will not $N$ in itself produce pulmonary hypertension but will potentiate the effects of other stimuli. Thus, an increase in pulmonary blood flow through the left lung (produced by ligation of the right pulmonary artery) leads to the development of pulmonary $\mathbb{\complement}$ hypertension in Denver, but not at sea level where mild hypoxia is absent (Vogel et al., 1967). Furthermore, we have shown that norepinephrine will increase pulmonary vascular resistance in the calf $\frac{\Omega}{\mathbb{D}}$ lung perfused at constant flow in situ (Silove, Inoue, and Grover, 1968). 
The calves studied during the present investigation had pulmonary vascular beds capable of marked vasoconstriction. Acute hypoxia doubled the total pulmonary vascular resistance and increased PPA to $40-40 \mathrm{mmHg}$. In contrast, PPA increased only $2-4 \mathrm{mmHg}$ following the injection of either aminorex or amphetamine, and this is no greater than the acute response to $6 \mathrm{ml}$ of saline alone. Consistent with this negative acute response was the absence of significant pulmonary hypertension following the chronic administration of these sympathomimetic drugs. However, in the aminorex group there was an upward trend in total pulmonary resistance (TPR) during normoxia and hypoxia over the 28 days. This trend did not achieve statistical significance in either case and none of the values was outside the normal range. It should be emphasized that TPR is not a very precise derivation, particularly during acute hypoxia in the calf.

These negative results with regard to the pulmonary circulation cannot be attributed to an ineffective dosage. Shortly after the injection of either aminorex or amphetamine, there was a transient sharp rise in systemic arterial pressure due to an increase in systemic vascular resistance, indicating the acute release of endogenous catecholamines. Tyramine had a similar effect. The dosage employed for aminorex, $0.25 \mathrm{mg} / \mathrm{kg}$, was approximately twice the human therapeutic dose.

A transient small increase in pulmonary artery pressure has been reported in dogs given intravenous aminorex, $10-160 \mathrm{mg} / \mathrm{kg}$ (Kraupp, Stühlinger, Raberger, and Turnheim, 1969). However, Will and Bisgard (1971) have recently shown that pure-bred beagle dogs, receiving either aminorex or amphetamine orally in doses of $1.5 \mathrm{mg} / \mathrm{kg}$ (sixfold greater than in the present study) for four days, failed to develop pulmonary hypertension. Chronic administration of aminorex to rats has also failed to produce any evidence of pulmonary hypertension (Kay, Smith and Heath, 1971).

This investigation has shown that neither aminorex nor amphetamine will produce pulmonary hypertension in the calf and indeed these sympathomimetic agents have not produced pulmonary hypertension in any experimental animal thus far tested. We must therefore conclude that neither aminorex nor amphetamine is an effective agent for the deliberate induction of experimental pulmonary hypertension. However, caution should be used in extrapolating the results of this study to man.
This study was supported by a grant from McNeil Laboratories, Inc., Fort Washington, Pennsylvania. We wish to thank Miss Gail Jamieson and Mr. John Pope for their excellent technical assistance. Mr. Harry Mills provided skilful assistance with the daily handling of the calves. We thank Miss Ruth Sackreiter for her careful preparation of the manuscript. Dr. ByrneQuinn was the recipient of a fellowship from the Colorado Heart Association, and Dr. Grover is the recipient of U.S. Public Health Service Research Career Development Award HE-29, 237.

\section{REFERENCES}

Chardonnens, J. D., and Mahaim, C. (1969). Hypertension pulmonaire après cure d'amaigrissement. Parxis, 58, 236.

Ferrer, M. I., Enson, Y., and Harvey, R. M. (1969). The hydrogen ion and pulmonary vasomotricity. Amer. Heart J., 78, 692.

Gaffney, T. E., Morrow, D. H., and Chidsey, C. A. (1962). The role of myocardial catecholamines in the response to tyramine. J. Pharmacol. exp. Ther., 137, 301.

Gurtner, H. P., Gertsch, M., Salzmann, C., Scherrer, M., Stucki, P., and Wyss, F. (1968). Häufen sich die primär vasculären Formen des chronischen Cor pulmonale? Schweiz. med. Wschr., 98, 1579, 1695.

Kaindl, F. (1969). Primäre pulmonale Hypertension. Wien. Z. inn. Med., 50, 451.

Kay, J. M., and Heath, D. (1969). Crotalaria Spectabilis: The Pulmonary Hypertension Plant. Thomas, Springfield, Illinois.

- Smith, P., and Heath, D. (1971). Aminorex and the pulmonary circulation. Thorax, 26, 262.

Kraupp, O., Stühlinger, W., Raberger, G., and Turnheim, K. (1969). Die Wirkung von Aminorex (Menocil) auf die Hämodynamik des kleinen und grossen Kreislaufs bei i.v. Darreichung am Hund. Naunym-Schmiedebergs Arch. Pharmak., 264, 389.

Poos, G. I., Carson, J. R., Rosenau, J. D., Roszkowski, A. P., Kelley, N. M., and McGowin, J. (1963). 2-amino-5Aryl-2-oxazolines. Potent new anorectic agents. $J$. med. Chem., 6, 266.

Reeves, J. T., Grover, R. F., Will, D. H., and Alexander, A. F. (1962). Haemodynamics in normal cattle. Circulat. Res., 10, 166.

Rivier, J. L. (1970). Hypertension artérielle pulmonaire primitive. Schweiz. Med. Wschr., 100, 143.

Scheffé, H. (1959). The Analysis of Variance. Wiley, New York.

Silove, E. D., Inoue, T., and Grover, R. F. (1968). Comparison of hypoxia, $\mathrm{pH}$, and sympathomimetic drugs on bovine pulmonary vasculature. J. appl. Physiol., 24, 355.

Stowe, C. M., and Good, A. L. (1960). Estimation of cardiac output in calves and sheep by the dye and Fick oxygen techniques. Amer. J. Physiol., 198, 987.

Vogel, J. H. K., McNamara, D. G., Hallman, G., Rosenberg, H., Jamieson, G., and McCrady, J. D. (1967). The effects of mild chronic hypoxia on the pulmonary circulation in calves with reactive pulmonary hypertension. Circulat. Res., 21, 661.

Will, J. A., and Bisgard, G. E. (1971). Hemodynamic effects of Aminorex ${ }^{(R)}$ in unanesthetized beagle dogs. Europ. $J$. Pharmacol. (In press.) 